9. Hnatiuk, V. (1909). Materials for Ukrainian ethnology. Vol. 12. Lviv: Shevchenko Scientific Society.

10. Medvedyk, P. (1987). Kurbas Spring Evenings (To the 100th anniversary of O. S. Kurbas). Zhovten [October], no. 4, pp. 80-88.

11. Onatskyi, Ye. (1958). Ukrainian small encyclopedia. In vol. 8. 16 Books Books 2. Buenos Aires: The Administration of the UAOC in Argentina, 1957-1967

12. Potebnya, A. (1883). Explanation of Little-Russian and related folk songs. Warsaw: Printing house of M. Zemkevich and V. Noskovsky.

13. Smoliak, O. (2001). The Spring Ceremony of Western Podillya in the Context of Ukrainian Culture. Monograph. Part 2. Ternopil: Aston.

14. Smoliak, O. (2001). Dance drawings in the haivkas of Western Podillya. Muzyka ta diia $v$ tradytsiinomu folklori: Zbirnyk naukovykh prats $[$ Music and Performance in Traditional Folklore: Collection of Scientific Papers]. pp. 56-68.

15. Taniuk, L. (2007). Talan and talent of Les Kurbas. Ministry of Culture and Tourism of Ukraine, L. Kurbas State Center of Theatre Arts, National Opera of Ukraine, State Enterprise "Art of Ukraine”. Kyiv.

(С) Смоляк О. С., 2018

УДК 792.73:7.097

\author{
Совгира Тетяна Ігорівна \\ кандидат мистецтвознавства, \\ Київський національний університет \\ культури і мистецттв, \\ Київ, Україна \\ STIsovgyra@gmail.com
}

\title{
ВИКОРИСТАННЯ ТЕХНІЧНИХ МОЖЛИВОСТЕЙ ВІЗУАЛЬНОГО МИСТЕЦТВА В СЦЕНІЧНОМУ ПРОСТОРІ
}

Мета роботи. Стаття присвячена дослідженню питань методики використання технічних можливостей візуального мистецтва у процесі створення сценічних розважальних заходів. Відповідно до мети з'ясовуються поняття «візуальне мистецтво», «техніка» та «технологія», «інтерактивність» тощо, досліджується специфіка тривимірного відеомеппінгу, відеоінсталяцій як напрямків сучасного мистецтва. Методи дослідження: в роботі застосовано загальнонаукові та конкретнонаукові методи: аналітичний - при аналізі філософської, мистецтвознавчої, культурологічної літератури 3 теми дослідження; історичний - для з'ясування етапів становлення напрямків відеоарту як мистецького явища; теоретичний - для з'ясування загальної природи візуального мистецтва та його специфіки в сфері сценічних мистецтв; порівняльно-типологічний - для виявлення рис подібності і відмінності сценічного та візуального мистецтв як видів мистецтва; концептуальний - при 
аналізі та характеристиці понятійно-термінологічної системи дослідження. Наукова новизна роботи полягає в тому, що вперше аналізуються питання використання інтерактивної медійної техніки в процесі виробництва розважально-видовищних заходів та відповідні проблеми 3 ii практичним впровадженням у сценічний простір. Висновки. Доведено, що використання технічної складової відео-арту в сценічному просторі надає йому особливої видовищності та інтерактивності. Завдання використання подібної візуалізації полягає в тому, щоб надати нерухомій дійсності рух та динаміці особливу образність. Нині існують вже приклади сценічних шоу-програм, які вповні організовані за рахунок зображально-виражальних засобів візуального мистецтва та в своїй організації не використовують основний засіб виразності сценічних видів мистецтва - акторську майстерність (сценічну дію актора). У сценічному просторі візуальні інсталяції можуть слугувати в ролі об’єкта, скульптури, декорацій.

Ключові слова: технологія, відео-арт, інтерактивність, сценічне мистецтво.

Совгира Татьяна Игоревна, кандидат искусствоведения, Киевский национальный университет культуры и искусств, Киев, Украина

Использование технических возможностей визуального искусства в сценическом пространстве

Цель работы. Статья посвящена исследованию вопросов методики использования технических возможностей визуального искусства в процессе создания сценических развлекательных мероприятий. В соответствии с целью работы выясняются понятия «визуальное искусство», «техника» и «технология», «интерактивность» и т.д., исследуется специфика трехмерного видеомеппинга, видеоинсталляций как направлений современного искусства. Методы исследования: в работе применены общенаучные и конкретнонаучные методы: аналитический - при анализе философской, искусствоведческой, культурологической литературы по теме исследования; исторический - для выяснения этапов становления направлений видео-арта как художественного явления; теоретический - для выяснения общей природы визуального искусства и его специфики в сфере исполнительского искусства; сравнительно-типологический - для выявления сходства и различия сценического и визуального искусств как видов искусства; концептуальный - при анализе и характеристике понятийнотерминологической системы исследования. Научная новизна работы заключается в том, что впервые анализируются вопросы использования интерактивной медийной техники в процессе производства развлекательнозрелищных мероприятий и соответствующие проблемы с ее практическим внедрением в сценическое пространство. Выводы. Доказано, что использование технической составляющей видео-арта в сценическом пространстве придает ему особой зрелищности и интерактивности. Задача использования подобной визуализации заключается в том, чтобы предоставить неподвижной действительности движение и динамику, особую образность. В настоящее время существуют уже примеры сценических шоу-программ, которые 
полностью организованы за счет изобразительно-выразительных средств визуального искусства и в своей организации не используют основное средство выразительности сценических видов искусства - актерское мастерство (сценическое действие актера). В сценическом пространстве визуальные инсталляции могут служить в качестве объекта, скульптуры, декораций.

Ключевые слова: технология, видео-арт, интерактивность, сценическое искусство.

Sovhyra Tetiana, PhD in Art Criticism, Kyiv National University of Culture and Arts, Kyiv, Ukraine

\section{Using technical opportunities of visual art in the acting space}

The purpose of the article is to investigate the problem of the methodology of using technical opportunities of visual art in the process of creating staged entertainment events. The concepts of «visual art», «technique» and «technology», «interactivity», etc. are clarified; the specificity of three-dimensional videomapping and video installations as areas of contemporary art are studied. The research methodology consisted in the application of the following general scientific and specific scientific methods: analytical - in the analysis of philosophical, art critical and culturological literature on the subject under research; historical - to determine the stages of formation of the areas of video art as an artistic phenomenon; theoretical - to define the general nature of visual art and its specifics in the field of performing arts; comparative-typological - to reveal commom and distinctive features of performing and visual arts as types of art; conceptual - in the process of analyzing and characterizing the conceptual-terminological system of the research. The scientific novelty of the work lies in the first attempt to consider the problems of using interactive media technology in the process of creating staged entertainment events and the corresponding problems of its practical implementation in the acting space. Conclusions. It was proved that using the technical component of video art in the acting space provides it with special visual appeal and interactivity. The task of using such visualization is to provide motionless reality with motion and dynamics with special imagery. Today, there are examples of stage shows which are fully organized using figurative-expressive means of visual art and do not use the main means of expression of the performing arts - acting (actor's performance). In the acting space, visual installations can serve as an object, sculpture, or stage setting.

Key words: technology, video art, interactivity, performing art.

Вступ. Візуальне мистецтво, інакше кажучи відео-арт, - явище досить молоде (вперше зародилося в США в 60-70 pp. ХХ ст.), однак надзвичайно популярне та амбітне в мистецькому просторі.

Тому цілком зрозумілий науковий інтерес до цього мистецтва: специфіка візуальних мистецьких напрямків розглянута у виступах арт-критика, керівника асоціації «Нове мистецтво» та Центру сучасного мистецтва Сороса М. Рашковецького («Історія одеського відеарту: короткий нарис»), на лекційних заняттях культуролога та мистецтвознавця Я. Пруденко («Відеоарт. 
Українська практика»), куратора та мистецтвознавця Н. Манжалій («Нові території мистецтва»: розвиток комп'ютерно-електронного мистецтва в Україні (кінець 1990 - х початок 2000-х). Естетичний аналіз арт-мистецтва проведено О. Ліщинською у статті «Медіа-арт в українському візуальному мистецтві: філософсько-естетичні ідеї та вияви», 2013 р., Я. Пруденко в статті «Рабле українського відео-арту. Олександр Ройтбурд» (онлайн-ресурс). Технологічні питання візуального мистецтва розглянуті в роботах Л. Ісаєва («Антологія російського відеоарту», 2002 р.), Г. Вишеславського (стаття «Відео-арт», 2009 р.). Історичний аспект арт-мистецтва досліджено в роботі В. Сидоренка «Візуальне мистецтво від авангардних зрушень до новітніх спрямувань: Розвиток візуального мистецтва України XX-XXI ст.», 2008 р.

Однак, незважаючи на суспільний інтерес до візуального мистецтва, немає жодної наукової роботи, в якій було б досліджена специфіка використання інтерактивних медійних технічних можливостей арт-мистецтва в сценічному просторі.

Тенденції сучасного сценічного мистецтва останнім часом демонструють появу нових засобів художньої виразності та способів мистецького самовираження, що виявляються в яскравому акцентуванні візуальновидовищного аспекту художніх форм та залученні нових оригінальних засобів художньої виразності.

Деяким чином продукція відео-арту служить митцям сцени декораціями та змінним реквізитом, надто - цікавим та оригінальним режисерським ходом та наскрізною дією вистави, концерту, іншого сценічного продукту (уточнюю, сценічний простір у даному контексті $\epsilon$ не лише традиційною формою театральної сценічної коробки, а й форми відкритих естрад та сценічних майданчиків просто неба, де $\epsilon$ можливим організувати будь-яку форму розважального видовища).

Мета роботи. Стаття присвячена дослідженню питань методики використання технічних можливостей візуального мистецтва у процесі створення сценічних розважальних заходів. Відповідно до мети з'ясовуються поняття «візуальне мистецтво», «техніка» та «технологія», «інтерактивність» тощо, досліджується специфіка тривимірного відеомеппінгу, відеоінсталяцій як напрямків сучасного мистецтва.

Виклад основного матеріалу. Надмірний інтерес діячів сцени, мистецтвознавців та глядачів зумовлює необхідність розгляду концептуального змісту поняття відео-арту, аналізу його основних мистецьких напрямків (відеомеппінгу та відеоінсталяцій) та проблеми вдалого застосування інтерактивної візуальної техніки в сценічному мистецтві з метою підсилення емоційного впливу на глядача.

Відео-арт (англ. video - візуальний, art - мистецтво) - напрям у мистецтві останньої третини XX ст., що використовує можливості відеотехніки.

На початку свого існування (перші експерименти датуються 1965 р.) візуальне мистецтво постало як принципово новий, оригінальний мистецький феномен. 
Не дивлячись на, здавалося б, технологічну спорідненість 3 кінематографом та телебаченням, мистецтво відео-арту продемонструвало свою відмінну специфіку та оригінальні виражально-зображальні можливості.

Розглянемо ці специфічні відмінності відповідно до технікотехнологічних особливостей відео-арту.

«Техніка», як відомо, знайоме поняття для мистецтва. Технологія ж, тобто логіка техніки, як слушно зауважує С. Безклубенко, будучи осмислена в своїй закономірності стає основою творчого методу, естетизована - стає зображально-виражальним засобом мистецтва.

«Важливі принципи технології виробництва продуктів для задоволення естетичних потреб, будучи усвідомлені як закономірні щодо виготовлення цих предметів, виступають як вихідні принципи творчості, поетичні принципи. Безперечно, вони не становлять самої сутності творчого методу, оскільки мистецтво - особливе, ідеологічне виробництво, але $\epsilon$ істотними для визначення цього методу» [3, с. 128]. Ці принципи визначають специфіку мистецтва 3 практичного, «ремісничого» розуміння. «Принципи технології виробництва предметів для задоволення естетичних потреб, - твердить С. Безклубенко, - визначають специфіку кожного виду мистецтва - те, чим один вид, або жанр відрізняється від іншого» [2, с. 97].

Технічною складовою виробництва відео-арт-продукту є застосування телеприймачів, відеокамер і моніторів, проекторів, екранів та ін. техніки, що використовується у виробництві медіа-продукту.

На основі кінематографічної та телевізійної техніки художники розробили нове приладдя для створення відеопродукту (матеріалу для візуального мистецтва) - відеосинтезатори, за допомогою яких стало можливим редагувати, колонізувати, мішкувати відеосигнали з різних камер, а значить перетворювати звичайне зображення в абстрактне (відбулося це в 60 рр. ХХ ст).

Загальне невдоволення населення США та Західної Свропи в 60 рр. XX ст. та протести проти діяльності корпоративних медіа та необ'єктивності влади призвели до експериментальних спроб зародження нового медійного інструменту для політичних та соціальних трансформацій - мистецтва відеоарту. На теренах СРСР візуальне мистецтво також зародилося в період політичних, економічних, соціальних перетворень та реформами, ініційованими горбачовською «перебудовою», однак сталося це на десятки років пізніше в 90 pp. ХХ ст.

Не маючи доступу до телевізійних каналів та професійного телевізійного обладнання, художники почали використовувати все те, що було доступним пересічному громадянину, а саме: теле- та радіоприймачі, портативні відеокамери для створення робіт критичного змісту (висміювання недоліків екранних медіа). Прикладом може слугувати робота одного із засновників відео-арту американського художника Нам Джун Пайка, який в одній з перших своїх інсталяцій встановив телеприймачі в скульптури, що нагадували «пісуар» Марселя Дюшана, в даному випадку, порівнюючи телевізор як об'єкт повсякденного використання 3 іншим аналогічним атрибутом. Автор 
пропонував глядачам за допомогою магніту змінити картинку на відеомоніторі, таким чином, додаючи своїм інсталяціям нову особливу якість інтерактивності.

Інтерактивність - особливість, яка характеризує мистецтво відео-арту та виокремлює 3-поміж інших.

Залучення відео-арту в сценічний простір дає можливість режисерові зробити видовище інтерактивним, що призводить до трансформації ролі глядача у видовищі: сценічний твір стає не просто об'єктом спостерігання, а й середовищем, в якому учасник-глядач залучається до самого дійства. Подібні зміни пов'язані 3 тим, що сучасна публіка вже не хоче просто спостерігати - глядач потребує сильних емоційних вражень та відчуттів, i тому він стає повноправним учасником видовища.

Останнім часом роботи відеохудожників, аніматорів та графістів представлені не тільки на галерейних виставках, а й в сценічному просторі.

Відео-арт - це складне комплексне явище, яке має стилістичні напрями та форми. Вони формувалися відповідно розвитку телевізійних, а потім і комп'ютерних технологій. Відео-арт пройшов кілька етапів розвитку: від експериментів та інтересу до функціональних можливостей та громадської ролі телебачення - до його використання як засобу вираження й екранного трактування актуальних тем i проблем нашого часу, i навіть як оригінальний художній напрямок у мистецтві.

На відміну від творів екранних мистецтв, телебачення та кінематографу, розрахованих на масового глядача, продукт відеоарту створюється для значно меншого кола глядачів (навіть у випадку великого масового заходу), має менший масштаб транслювання та демонстрації.

Основна відмінність відео-арту від кінематографу полягає у відсутності сюжетності та описовості. Відеомистецтво не потребує акторської майстерності, наявності драматургії, викладу «історії про героїв». Принцип побудови таких екранних робіт $є$ тематичним: темою може слугувати актуалізація соціальних та культурних питань, загально-філософських та естетичних проблем тощо.

Розглянемо жанри візуального мистецтва за їх технічною та специфічною складовими та можливість їхнього впровадження в сценічний простір.

Відеоінсталяції (з англ. Video installation) - жанр візуального мистецтва, що $є$ одно- або мультиекранною проекцією, де ключова роль належить відеозображенню на моніторах або проекційних екранах [1, с. 192].

Термін «інсталяція» походить від англійського дієслова «to install» (встановлювати), що з'ясовує сутність поняття та розкриває технічний аспект виготовлення інсталяції: іï не «виготовляють», «малюють», «пишуть», а саме встановлюють, складають, формують 3 окремих частин.

Елементами інсталяції можуть бути різні об'єкти, зокрема й предмети, малюнки, людина, звук, віртуальна реальність, відеоматеріал, інтернет тощо.

У сценічному просторі інсталяція може використовуватися в ролі об'єкта, скульптури, декорації. Застосування інсталяцій сприймається як експериментальне поєднання сценічного та візуального мистецтв. Показовим 
прикладом $є$ синтетична постановка «Червоних птах» польського режисера Войтека Урбанські - вистава, в драматургічній основі якої закладене поєднання тексту з театральною формою та художньою умовністю.

Однак нас цікавить саме сценічний простір, тому звернемо увагу на відео інсталяції, а також технології тривимірного відеомеппінгу - технологію, що дозволяє проектувати зображення та відеоряд на різні нерівні поверхні.

За допомогою меппінгу виникає можливість організувати як в приміщенні та сценічному просторі, так i на вулицях міста візуальні вражаючі шоупрограми.

Зазвичай, тривимірний відеомеппінг використовується для трансляції проекційного шоу на фасадах будівель, екранах та інших площинах - не завжди рівних та одновимірних - для чого створюється індивідуальний для кожного фасаду будівлі тривимірний відеоролик, що має на меті «обіграти» та підкреслити архітектурні деталі споруди. Майстри тривимірного меппінгу створюють вражаючі візуальні ілюзійні зображення динамічної геометрії простору та дивовижні картини.

Уперше тривимірну відеоінсталляцію, створену для презентації телевізорів Samsung 3d LED, було зображено на історичній будівлі Біржі Берлаге жителям і гостям Амстердама. Пізніше ця технологія тривимірного проектування, яка вважалася «дивиною» набула широкого й практичного застосування в режисерів-постановників вуличних розважальних та комерційних заходів.

Технологічний процес створення тривимірної проекції вкрай складний та довготривалий. Графічне видовище, тривалістю в одну хвилину, вимагає довгої клопіткої роботи фотографів, художників та інженерів. Будівлю, на якій заплановано створити проекцію, довго вивчають. Чим рельєфніша поверхня фасаду та більше на ньому скла та інших світловідбиваючих матеріалів, тим складнішим стає завдання (до речі: вікна на фасаді мають бути заклеєні 3 внутрішньої сторони білим папером, щоб промені проекції не пробивали скло та не розповсюджувалися всередині кімнат будівлі).

Ключовим моментом, на думку провідних графітів, є народження ідеї. Далі - пишеться сценарій, створюється розкадровка та починається процес створення зображення за допомогою графічного редактора. Повна відповідальність за створення візуального креативного рішення покладена на плечі художника проекту.

За словами меппінг-художників, в основі будь-якого відеомеппінгу лежить сюжет (уточнюю, сюжет графічного зображення). Без сюжету меппінгпродукт перетворюється на сукупність графічних зображень, втрачаючи при цьому свою самостійність, завершеність форми та художню значимість. Завдання майстрів - поділитися 3 глядачем історією, донести ідею за допомогою анімації, сучасних можливостей медійних засобів (музики, звуку, зображення).

За допомогою графічних редакторів художник задає траєкторію руху героя (глядача), а потім - анімує зображення. 
Проекція готового відеоряду на фасад будівлі також вимагає значних зусиль та технологічної точності. Основними кольорами відеоряду, що проектується на будівлю, є здебільшого білий, рідше - зелений, синій, червоний (основні кольори моделі RGB) через те, що існує великий ризик неточного проектування кольорової гамми на відкритому просторі. Проекторів має бути декілька для отримання тривимірного зображення. Проблем щодо здійснення проекції на вулиці виникає досить багато.

Прикладом може слугувати відкриття електротеатру «Станіславський» (вул. Тверська, м. Москва, 2015 р.). Для проекції на фасад театру необхідно було розташувати проектори навпроти будівлі - через дорогу на паралельному боці вулиці. Відстань була дуже великою та й освітлення однієї з центральних вулиць міста - потужним для проекції відеоряду. Сдиним вдалим вирішенням такого завдання було розташування значної кількості проекторів, які б дублювали зображення в однакових ділянках будівлі, що значно збільшило витрати на проекції тривимірного зображення.

Використання такої технології має підтримку у великої аудиторії iï прихильників, оскільки на кожне подібне видовище збираються тисячі глядачів, які не лише дивляться й захоплюються ним, але й записують його на відеокамери, після чого викладають в Інтернет, де відеоролик переглядають ще декілька тисяч людей.

Використання технології тривимірного проектування можливо побачити в берлінському театрі AKHE на виставі «Depot of genius delusions» (прем'єра відбулася в 2012 р.). Це той випадок, коли сценічне видовище вповні організоване за участі тривимірного меппінгу. Платформа, на якій розташована глядацька аудиторія, повільно повертається. Глядачі в постійному русі можуть споглядати на гру акторів та проекційний відеоряд, які також рухаються навколо них. Актори на сцені повинні чітко підлаштовуватися під відеоряд та знати свої мізансцени (точне місцерозташування на сцені відповідно до глядача, акторів та тривимірної проекції). Це сценічне дійство вражає взаємодією живого акторського складу та технології проекції заздалегідь записаного та відтвореного відеоряду.

Інший приклад, не менш вражаючий, - триденна постановка-трилогія режисера московського електротеатру «Станіславський» Б. Юхананова (прем'єра відбулась 25 лютого 2015 р.), в якій казка М. Метерлінка переплітається 3 особистими спогадами акторів театру ім. К. С. Станіславського - Алефтіни Константинової та Володимира Коренєва (вони ж грають головних героїв: Тільтіля та Митиль). Проекційний відеоряд (створювався художником I. Ісаєвим упродовж цілого календарного року) повністю замінює у виставі декорації, з легкістю змінюючи обставини дії: за допомогою спецефектів глядач опиняється в зимовому аеропорту, в спекотному Баку, під водою або на сторінках рукопису Достоєвського. Окрім цього, невимушено з'являються рухомі зображення невагомого снігу чи туману, води та хмар, що підсилює емоційне забарвлення вистави. 
Однак вистави, в яких використовується технологія відеомеппінгу, є «не пересувними» (з ними вкрай важко гастролювати) з тієї причини, що відеоряд меппінгу вимагає точного розташування проекторів, відповідність сценічного майданчика до глядацької аудиторії, чітко визначені мізансцени акторського складу відповідно до проекції. Окрім того, необхідно знайти відповідні місця для встановлення відеопроекторів (найчастіше вони розміщуються високо над глядацькою залою та проектуються під кутом, щоб зображення проектувалося на глядачів, акторів та можливі декорації.

На естрадній сцені відеомеппінг використовується досить часто. Відеомеппінг може відтворюватись не тільки на проекційних екранах, а й на плазменних екранах. У цьому контексті наочним прикладом видається виступ естрадної співачки Софії Ротару з піснею «Одна калина» на концерті «Мрія про Україну» 3 нагоди святкування річниці незалежності України. За задумом режисера-постановника Олени Коляденко було анімовано картини Івана Горобчука («Веселий дід», «В осіннім саду», «Заготівля сіна» тощо) на плазменних моніторах, що надало виступу фольклорного автентичного колориту.

Завдання кожного сценографа - повне занурення в концепцію даної роботи, зміна настрою глядачів та незмінне бажання дивувати публіку.

Сучасні технології дозволяють досягати руху відеоповерхонь у всьому сценічному простору і навіть глядацькій залі в різних площинах за допомогою поворотних та розсувних механізмів, а також динамічних лебідок, з'єднуватися в одну площину й розщеплюватисяна дрібні частини.

Нині ця технологія використовується не тільки в сценічному просторі, або в проекціх на фасади будівель, а й на комерційно-корпоративних заходах, конференціях, рекламних проектах, презентаціях продукції тощо.

Новітнім $є$ метод меппінгу на одяг або навіть людське тіло, надто в динамічному русі. Цей спосіб проекції набув популярності на великих шоупрограмах артистів світового рівня.

Голографічні моделі - ще одна інтерактивна технологія сучасного мистецтва. Прикладів використання голографічних проектів у сценічному просторі досить багато, однак найбільш вражаючим та довготривалим, на нашу думку, є проект «Міку Хацуне» японської компанії Crypton Future Media, який 31 серпня 2007 р. зобразив однойменну голографічну модель, що уособлює японську віртуальну співачку та є кумиром багатьох японських підлітків. За допомогою технології тривимірної проекції на напівпрозорий екран, вона (модель) виступає на сценічному майданчику перед багатомільйонною аудиторією, приймає участь у зйомках телевізійних шоу-проектів, рекламних промо-роликах тощо.

Наукова новизна роботи полягає в тому, що вперше аналізуються питання використання інтерактивної медійної техніки в процесі виробництва розважально-видовищних заходів та відповідні проблеми 3 ii практичним впровадженням у сценічний простір. 
Висновки. Використання зображально-виражальних засобів відео-арту в сценічному просторі надає останньому особливої видовищності та інтерактивності. Відеомеппінг та віджеїнг - досить молоді напрямки візуального мистецтва, які можливо застосовувати в сценічному просторі для демонстрації продукції, зовнішньої реклами та внутрішнього декоративного оформлення сцени. Сьогодні вже існують видовищні заходи, які повністю виконані за допомогою технічної складової форм відео-арту, без живої акторської гри. Шоу-програми, в яких використовується технологія тривимірного меппінгу, - це сучасні видовищні вистави. Завдання подібної візуалізації полягає в тому, щоб надати нерухомій дійсності рух, динаміку. У сценічному просторі візуальні інсталяції можуть слугувати в ролі об'єкта, скульптури, декорацій.

Однак, враховуючи динаміку розвитку креативних технологій та впровадження їх у сценічне мистецтво, вважаємо за потрібне в подальшому досліджувати нові технологічні можливості сучасного сценічно-розважального контенту.

\section{Список використаних джерел}

1. Антология российского видеоарта / [сост. А. Исаев]. - Москва: Медиа Арт Лаб, 2002. - 192 с.

2. Безклубенко С. Д. Грани творческого метода / С. Д. Безклубенко. Київ : Искусство, 1986. - 196 с.

3. Безклубенко С. Д. Суцільна природа мистецтва / С. Д. Безклубенко. Київ : Мистецтво, 1972. - 283 с.

4. Вишеславський Г. А. Відео-арт / Г. А. Вишеславський // Сучасне мистецтво: наук. зб. - Київ: Фенікс, 2009. - Вип. 4. - С. 53-70.

5. Ліщинська О. І. Медіа-арт в українському візуальному мистецтві: філософсько- естетичні ідеї та вияви / О. І. Ліщинська // Гілея: наук. вісн. Київ : Гілея, 2013. - № 78. - С. 256-259.

6. Пруденко Я. Рабле українського відео-арту. Олександр Ройтбурд [Електронний ресурс] / Я. Д. Пруденко. - Режим доступу: http://old.korydor.in.ua/texts/176-Rable-ukrainskogo-video-artu-OleksandrRoytburd - Назва з екрану. - Дата звернення 11.02.2018.

7. Сидоренко В. Візуальне мистецтво від авангардних зрушень до новітніх спрямувань: розвиток візуального мистецтва України XX-XXI ст. / В. Сидоренко. - Київ : ВХ студіо, 2008. - 187 с.

\section{References}

1. Isaev, A. (Ed.) (2002). The anthology of Russian video art. Moscow: Media Art Lab.

2. Bezklubenko, S. (1986). The facets of the creative method. Kyiv: Art.

3. Bezklubenko, S. (1972). The solid nature of art. Kyiv: Art.

4. Vysheslavskyi, H. (2009). 'Video-art'. Suchasne mystetstvo [Modern Art], vol. 
5. Lishchynska, O. (2013). 'Media art in Ukrainian visual art: philosophical and aesthetic ideas and expressions'. Hileia : naukovyi visnyk [Gilea: Scientific Bulletin], no. 78, pp. 256-259.

6. Prudenko, Ya. (2018). 'The Rabelais of Ukrainian video art. Oleksandr Roitburd', [online] Available at: <http://korydor.in.ua/texts/176-Rable-ukrainskogovideo-artu-Oleksandr-Roytburd> [Accessed 11 February 2018].

7. Sydorenko, V. (2008). Visual art from avant-garde shifts to new directions: the development of visual art of Ukraine in the $20^{\text {th }}$ and $21^{\text {st }}$ centuries. Kyiv: VH studio.

(C) Совгира T. I., 2018

УДК 791.22(477)“1953/1964”(075)

Сокол Олена Володимирівна здобувач, Київький національний університет культури і мистеитв, Київ, Україна sokolee@ukr.net

\section{ТВОРЧИЙ ВСЕСВІТ КІНЕМАТОГРАФУ Т. В. ЛЕВЧУКА ПЕРІОДУ ХРУЩОВСЬКОЇ «ВІДЛИГИ»}

Мета дослідження. Стаття присвячена творчій та громадській діяльності провідного українського радянського кінорежисера Т. В. Левчука в 19531964-х рр.: аналізується творчий доробок митця в контексті специфіки українського кіновиробництва, його діяльність в Спілці кінематографістів УРСР. Методологію статті становлять принципи об'єктивності та історизму, які базуються на проблемно-хронологічному, конкретно-історичному, описовому статистичному та логіко-аналітичному методах наукового пізнання. Наукова новизна статті полягає у висвітленні діяльності українського кінорежисера Т. В. Левчука в період хрущовської «відлиги», з використанням архівних матеріалів Київського національного університету театру, кіно і телебачення ім. І. К. Карпенка-Карого, фондів музею Національної кіностудії художніх фільмів ім. О. Довженка, критичних статей та рецензій, опублікованих у періодичній пресі, а також мемуарної літератури. Висновки. Особистий внесок Т. В. Левчука в розвиток українського кіновиробництва та професійної мистецької освіти важко переоцінити: за його поданням у 1961 p. Ради Міністрів УРСР ухвалила рішення про відкриття в Київському інституті театрального мистецтва кінофакультету, який повинен здійснити підготовку кадрів за спеціальностями: кінорежисура, кінооператорство та кінознавство; наслідком його педагогічної діяльності $\epsilon$ виховання славетної когорти кінорежисерів; а творчої діяльності - художньо-ігрові фільми: «Полум'я гніву» 